\title{
Establishment and Maintenance of Neural Circuit Architecture
}

\author{
Emily L. Heckman and Chris Q. Doe \\ Institute of Neuroscience, Institute of Molecular Biology, Howard Hughes Medical Institute, University of Oregon, Eugene, Oregon 97403
}

The ability to sense the world, process information, and navigate the environment depends on the assembly and continuous function of neural circuits in the brain. Within the past two decades, new technologies have rapidly advanced our understanding of how neural circuits are wired during development and how they are stably maintained, often for years. Electron microscopy reconstructions of model organism connectomes have provided a map of the stereotyped (and variable) connections in the brain; advanced light microscopy techniques have enabled direct observation of the cellular dynamics that underlie circuit construction and maintenance; transcriptomic and proteomic surveys of both developing and mature neurons have provided insights into the molecular and genetic programs governing circuit establishment and maintenance; and advanced genetic techniques have allowed for high-throughput discovery of wiring regulators. These tools have empowered scientists to rapidly generate and test hypotheses about how circuits establish and maintain connectivity. Thus, the set of principles governing circuit formation and maintenance have been expanded. These principles are discussed in this review.

\section{Introduction}

The steps from when a neuron is born to when it becomes functionally embedded within a circuit have been defined, even if the relevant molecular mechanisms often remain unclear. These steps include extending processes through a complex extracellular environment, terminating in the proper location, identifying the correct partner neurons, and establishing synapses within a specific subcellular domain of those neurons. In this review, we focus on how neurons establish and maintain synapses with the correct cellular and subcellular specificity and refer the reader to other reviews on the preceding steps (Dickson, 2002; Kolodkin and Tessier-Lavigne, 2011; Chédotal, 2019).

\section{How do neurons establish specific wiring patterns?}

Full or partial electron microscopy reconstructions of model organism connectomes have provided a reference to identify neurons that are synaptically connected, the number of synapses between connected neurons, and the structural variability of those synaptic connections within and between animals (White et al., 1986; Kasthuri et al., 2015; Schneider-Mizell et al., 2016; Gerhard et al., 2017; Hildebrand et al., 2017; Mark et al., 2019; Scheffer, 2020; Valdes-Aleman et al., 2020; Witvliet et al., 2020). From these studies, it is clear that neurons form synapses with only a subset of adjacent neurons. The specificity with which one

\footnotetext{
Received July 30, 2020; revised Nov. 29, 2020; accepted Dec. 9, 2020.

The authors declare no competing financial interests.

This work was supported by Howard Hughes Medical Institute and National Institutes of Health R37 HD27056. We thank Chundi Xu, Abagael Lasseigne, and Sarah Ackerman for thoughtful comments on the outline and manuscript. We apologize to our colleagues whose work may have been inadvertently excluded from this review.

Correspondence should be addressed to Emily L. Heckman at heckman.em@gmail.com or Chris Q. Doe at cdoe@uoregon.edu.

https://doi.org/10.1523/JNEUROSCl.1143-20.2020

Copyright $\odot 2021$ the authors
}

neuron forms synapses with another neuron is referred to as cellular synaptic specificity (Fig. $1 A$ ). This specificity implies the existence of partner-derived cues that promote the formation of specific connections and preclude connections with others. Below we summarize key mechanisms that promote the establishment of synaptic specificity.

\section{Cell-surface cues establish synaptic specificity}

One hypothesis established $>100$ years ago is the chemoaffinity hypothesis (Langley, 1895; Sperry, 1963), which posits that neurons are endowed with unique molecular tags that enable them to recognize and to be recognized by their appropriate synaptic partners. The hypothesis was published in 1895 by John Langley, who observed that individual spinal cord neurons in the cat innervate specific peripheral organs. After severing the neurons and allowing them to regenerate, the neurons managed to form synapses with their original partners. These findings were later replicated and expanded on by Roger Sperry in the retinotectal system of amphibians. After severing the optic nerve and observing the return of normal vision (Sperry, 1943, 1944), Sperry concluded, "that the cells and fibers of the brain and cord must carry some kind of individual identification tags" (Sperry, 1963).

The chemoaffinity hypothesis put forth by Langley and Sperry generates several predictions about the molecules that could serve as partner-derived cues: (1) the molecules are expressed at the time of synapse formation; (2) the molecules are expressed in complementary patterns within presynaptic and postsynaptic neurons; (3) nonsynaptic partners express less compatible molecules; and (4) removal or ectopic addition of the molecule should result in circuit miswiring (Fig. 2). Since Langley's and Sperry's original studies, molecules that fit some or all of these criteria have been identified across a variety of model organisms (Table 1). Many of these molecules are broadly classified as cell adhesion molecules (CAMs). 


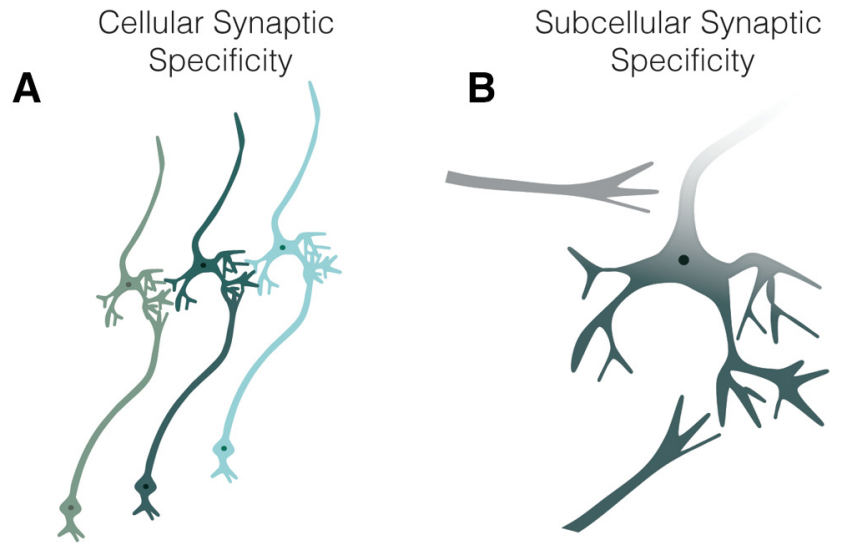

Figure 1. Distinction between cellular and subcellular synaptic specificity. $\boldsymbol{A}$, Neurons can preferentially form synapses with subsets of other neurons. $\boldsymbol{B}$, Neurons can preferentially form synapses at specific subcellular locations.

CAMs are transmembrane proteins that have homophilic or heterophilic interactions to promote cell-cell adhesion or cell-cell signaling (Williams et al., 2010; de Wit and Ghosh, 2016).

Recent work in Drosophila tested the extent to which cell-surface cues versus location determine synaptic specificity, while also highlighting the power of electron microscopy to assay experimental manipulations of synapse number and connectivity (Valdes-Aleman et al., 2020). The axons of a specific class of larval sensory neuron were mistargeted from a medial to a lateral position of the neuropil through the misexpression of a receptor for a midline-expressed repulsive guidance cue. Valdes-Aleman et al. (2020) asked whether the mistargeted axons would retain synaptic specificity in their ectopic location. The mistargeted neurons and all postsynaptic partners were reconstructed using electron microscopy. Surprisingly, the dendrites of postsynaptic partner neurons extended into the ectopic territory and successfully located the sensory axons. The mistargeted neurons indeed retained the same cellular synaptic specificity (Valdes-Aleman et al., 2020). These findings provide evidence that partner-derived cues, rather than physical proximity, determines synaptic partner matching in this context.

High-throughput methods have been leveraged to expand the palette of CAMs that promote cellular synaptic specificity. For example, recent work in Drosophila has defined an extracellular "interactome" of 202 CAMs, including immunoglobulin (IgSF) proteins, leucine-rich repeat proteins, and fibronectin Type III proteins (Özkan et al., 2013). To test the extracellular binding affinities among these proteins, a novel bait-and-prey assay was developed. After testing over 20,000 pairwise interactions with this assay, 106 unique interactions were identified, of which $\sim 80 \%$ had not previously been reported. Among these novel interactions were those between IgSF proteins from two uncharacterized protein families, the Dprs (Defective in Proboscis extension Response) and DIPs (Dpr-Interacting Proteins) (Nakamura et al., 2002; Özkan et al., 2013; Carrillo et al., 2015). In vitro, the extracellular domains of the 21 Dprs and 11 DIPs largely bind in a heterophilic manner. A single Dpr preferentially binds between one and four DIPs, and a single DIP can bind between two and nine Dprs (Özkan et al., 2013; Carrillo et al., 2015; Cosmanescu et al., 2018; Sergeeva et al., 2020). Given the specificity of their extracellular interactions in vitro, it has been hypothesized that Dprs/DIPs act to identify and promote selective interactions between synaptic partners.
These hypotheses have recently been experimentally tested. For example, DIP- $\beta$ mRNA and protein were found to be uniquely expressed in L4 lamina neurons in the visual system (Tan et al., 2015; C. Xu et al., 2019). Next, to examine whether DIP- $\beta$ is necessary for L4 to synapse with its known partner L2 in the proximal lamina, dip- $\beta$ was knocked down in L4 neurons. L4-L2 synapses still formed in the proximal lamina, but there were also ectopic synapses in the distal lamina. This suggested that DIP- $\beta$ is not required for synapse formation, but instead may have a role in promoting synaptic specificity by limiting the preferred postsynaptic partners of L4. To test if DIPs are sufficient to specify synaptic partnerships, DIP- $\beta$ or DIP- $\gamma$ were misexpressed in nonpartner lamina neurons. This resulted in novel, aberrant connectivity. Similar results have been observed at the larval neuromuscular junction (Ashley et al., 2019; Cheng et al., 2019). Therefore, DIP expression is not necessary for synapse formation per se, but rather biases the connectivity preference of a neuron (C. Xu et al., 2019), leading to synaptic specificity.

The discovery and functional characterization of the DIPs and Dprs highlight how high-throughput techniques have been leveraged to refine our understanding of how cellular synaptic specificity is established. While we chose to focus our attention on the DIPs and Dprs, many other CAMs promote cellular synaptic specificity (Fig. 3A), through a variety of mechanisms (Sanes and Yamagata, 2009; Sanes and Zipursky, 2020). It is important to note that CAMs can serve different functions (e.g., axon targeting, partner matching, synapse maintenance) (Table 1) depending on the context (Barish et al., 2018). Some of the molecules that promote cellular synaptic specificity may also be required for subcellular synaptic specificity (discussed below) (Fig. $1 B$ ), and vice versa, but in many cases this distinction will require future experiments. Therefore, special care must be given interpreting phenotypes and assigning functions to potential synaptic specificity molecules.

\section{Secreted signaling molecules establish subcellular synaptic specificity}

An important component of neural circuit function is the subcellular location of a synapse on a neuron. Functional and modeling studies suggest that subcellular synapse location is critical for neuronal computations, including the timing of action potential generation, dendritic integration, and coincidence detection (Miles et al., 1996; Hao et al., 2009; Pouille et al., 2013; Bloss et al., 2016; Tobin et al., 2017; L. Wang et al., 2020). In many cases, neurons selectively form synapses at specific subcellular locations along their partners, referred to here as subcellular synaptic specificity (Fig. $1 B$ ). For example, in the mouse cortex and cerebellum, excitatory neurons are innervated at specific locations by different inhibitory interneuron subtypes (Ango et al., 2004; Huang, 2006; Favuzzi et al., 2019; Tai et al., 2019). Despite the functional importance of subcellular synaptic targeting, the precise mechanisms that establish subcellular synaptic specificity are still being uncovered.

Studies in invertebrates have highlighted the importance of secreted signaling molecules in establishing subcellular synaptic specificity (Fig. 3B,C). For example, in the Drosophila ventral nerve cord (analogous to the vertebrate spinal cord), the segmentally repeated A08a interneuron has two spatially distinct dendritic arbors: one positioned medially and the other laterally. Many presynaptic neurons synapse with just the medial or lateral dendrite, but never both (Sales et al., 2019). Interestingly, the A02l and $A 31 x$ neurons specifically target the lateral dendrite, but 

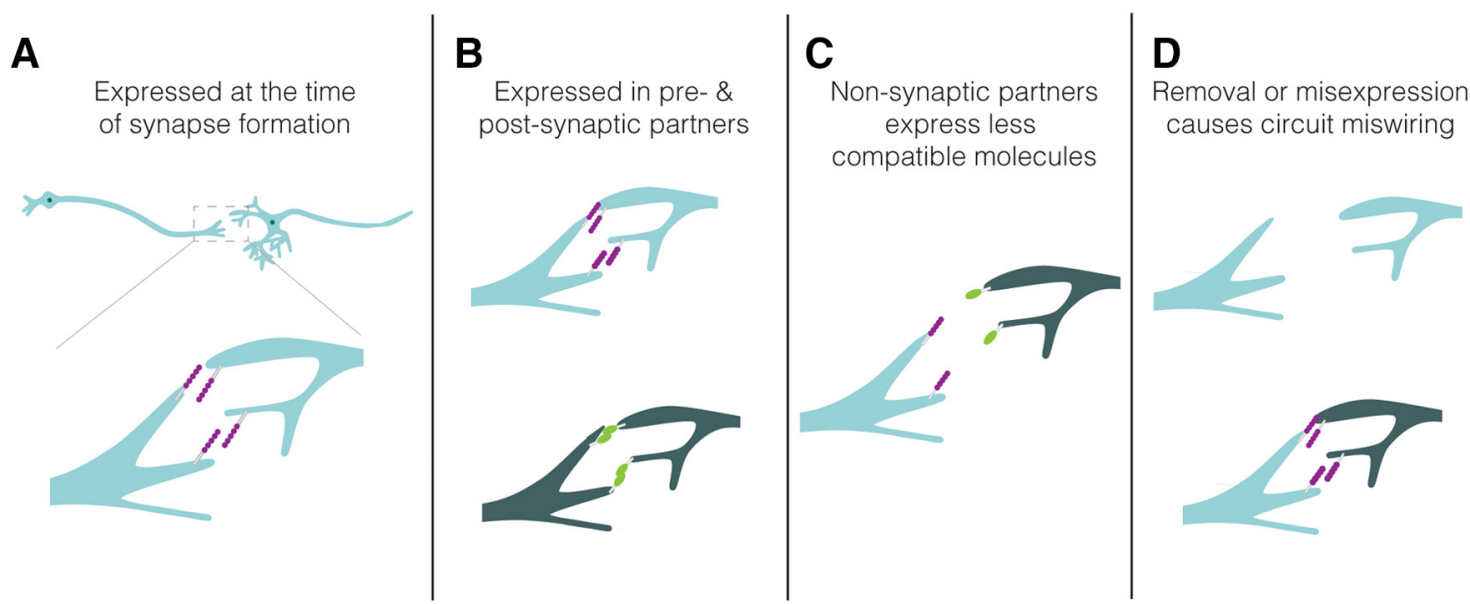

Figure 2. Features of proteins that promote synaptic specificity. $\boldsymbol{A}$, Molecules that specify connectivity should be at the time of synapse formation. $\boldsymbol{B}$, High-affinity molecules should be expressed in presynaptic and postsynaptic neurons. $\boldsymbol{C}$, Nonsynaptic partners should express molecules with relatively low affinity. $\boldsymbol{D}$, Manipulation of molecule expression (removal or misexpression) should result in circuit miswiring.

Table 1. Mechanisms of circuit establishment and maintenance

\begin{tabular}{|c|c|c|c|}
\hline Mechanism & Role & Proteins & References \\
\hline \multirow[t]{2}{*}{$\begin{array}{l}\text { Neuronal cell surface } \\
\text { interactions }\end{array}$} & Circuit establishment & $\begin{array}{l}\text { Teneurins, L1-CAM, DIPs/Dprs, Semaphorin/plexin, SYG, } \\
\text { Cadherins, Protocadherins, Sidekicks, Kirrels, Leucine-rich } \\
\text { repeats, LAR, Dystroglycan, Neurexin/Neuroligin }\end{array}$ & $\begin{array}{l}\text { Nose et al., 1997; Lee et al., 2001; Yamagata et al., 2002; Shen and } \\
\text { Bargmann, 2003; Ango et al., 2004; Shen et al., 2004; Prakash et al., } \\
\text { 2005; Dean and Dresbach, 2006; Serizawa et al., 2006; Chen and } \\
\text { Clandinin, 2008; Kurusu et al., 2008; Yamagata and Sanes, 2008; } \\
\text { Woo et al., 2009; DeNardo et al., 2012; Hong et al., 2012; Mosca et } \\
\text { al., 2012; Antinucci et al., 2013; Enneking et al., 2013; Mizumoto and } \\
\text { Shen, 2013; Schwabe et al., 2013; Soto et al., 2013; Ashrafi et al.., } \\
\text { 2014; Duan et al., 2014; Kuwako et al., 2014; Lüthy et al., 2014; } \\
\text { Krishnaswamy et al., 2015; Martin et al., 2015; Früh et al., 2016; } \\
\text { Mountoufaris et al., 2017; X. Xie et al., 2017; Berns et al., 2018; } \\
\text { Ashley et al., 2019; Cheng et al., 2019; Courgeon and Desplan, 2019; } \\
\text { Menon et al., 2019; Tai et al., 2019; Vaddadi et al., 2019; Q. Xie et } \\
\text { al., 2019; S. Xu et al., 2018; C. Xu et al.., } 2019\end{array}$ \\
\hline & Circuit maintenance & L1-CAM, LAR, Fasll, Dystroglycan, Netrin-G ligand, SynCAM & $\begin{array}{l}\text { Schuster et al., 1996; Dunah et al., 2005; Robbins et al., 2010; Zonta et } \\
\text { al., 2011; Enneking et al., 2013; Früh et al., 2016; Soto et al., 2018; } \\
\text { Tai et al., } 2019\end{array}$ \\
\hline \multirow[t]{2}{*}{ Secreted signaling } & Circuit establishment & Netrin, Wnt, Cbln, Semaphorin & $\begin{array}{l}\text { Colón-Ramos et al., 2007; Klassen and Shen, 2007; Poon et al., 2008; } \\
\text { Telley et al., 2016; Favuzzi et al., } 2019\end{array}$ \\
\hline & Circuit maintenance & ZIG & Aurelio et al., 2002; Bénard et al., 2009 \\
\hline \multirow[t]{2}{*}{ Neuronal activity } & Circuit establishment & Olfactory receptors & $\begin{array}{l}\text { Yu et al., 2004; Kerschensteiner et al., 2009; Prieto-Godino et al., 2012; } \\
\text { Inoue et al., 2018; Antón-Bolaños et al., 2019; Nakashima et al., } \\
\text { 2019; Valdes-Aleman et al., } 2020\end{array}$ \\
\hline & Circuit maintenance & GABA & Verhage et al., 2000; Yu et al., 2004; Schubert et al., 2013 \\
\hline \multirow[t]{2}{*}{ Glia-neuron interaction } & Circuit establishment & CHL1, Glypican, Ephrin, Neurexin/Neuroligin & $\begin{array}{l}\text { Ango et al., 2008; Allen et al., 2012; Ackerman et al., 2020; A. Q. } \\
\text { Nguyen et al., } 2020\end{array}$ \\
\hline & Circuit maintenance & EGL-15/FGF receptor, CIMA-1 & Shao et al., 2013 \\
\hline Growth restriction & Circuit maintenance & TaоK & Tenedini et al., 2019 \\
\hline Structural reinforcement & Circuit maintenance & ECM, Integrins, Ankyrin, Cytoskeleton & Orlando et al., 2012; de Vivo et al., 2013; Enneking et al., 2013 \\
\hline
\end{tabular}

their projections arise contralaterally and they simply bypass the medial dendrite (Sales et al., 2019). Similarly, the dbd sensory neuron projects ipsilaterally from the periphery and bypasses the lateral dendrite to specifically synapse with the medial A08a arbor (Schneider-Mizell et al., 2016; Sales et al., 2019). To determine how the dbd axon precisely targets the medial A08a dendritic arbor, Sales et al. (2019) generated two hypotheses: either (1) secreted guidance cues directly steer the dbd axon to the medial arbor, precluding any interaction with the lateral arbor or (2) the two A08a dendritic arbors express distinct CAMs that make dbd competent to synapse onto the medial, but not the lateral, dendritic arbor. The first hypothesis predicts that if dbd were redirected to the lateral arbor, it would form synapses at that location, whereas according to the second hypothesis, synapse formation would not occur because of incompatible cell-surface interactions. The authors shifted the dbd axon laterally by overexpressing the netrin receptor Unc-5. Netrin is secreted from the midline, and when it binds the Unc-5 receptor, a repulsive signal is transmitted to the developing neurite (Keleman and Dickson, 2001). This manipulation positioned the dbd axon terminal adjacent to the A08a lateral arbor. In this new subcellular location, dbd formed functional synapses with the A08a lateral arbor, as 
A
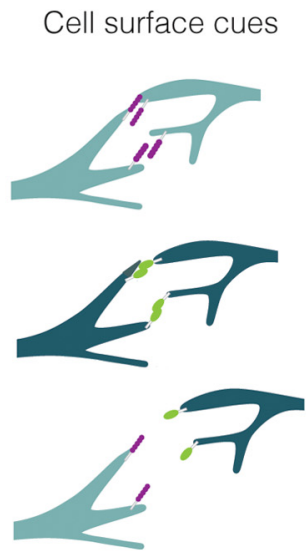

B Secreted cues can determine presynapse location

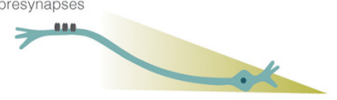

C Secreted cues can determine postsynapse location

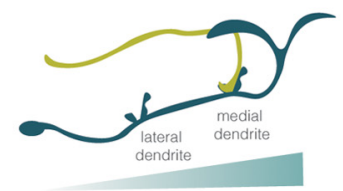

D Neuronal activity

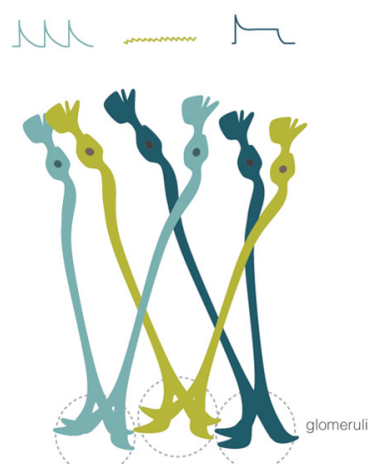

Figure 3. Mechanisms that promote the establishment of synaptic specificity. $\boldsymbol{A}$, Cell surface cues can promote the proper matching of presynaptic and postsynaptic partners. $\boldsymbol{B}$, Secreted cues can specify the subcellular location of presynapses. Adapted from Klassen and Shen (2007). C, Secreted cues can specify the subcellular location of postsynaptic sites. Adapted from Sales et al. (2019). D, Patterns of spontaneous neuronal activity influence the organization of OSNs into discrete glomeruli. Adapted from Nakashima et al. (2019).

observed through optogenetic activation of dbd and simultaneous recording of A08a $\mathrm{Ca}^{2+}$ responses (Sales et al., 2019). Therefore, in this system, the first hypothesis is supported: secreted guidance cues steer the dbd axon to the A08a medial dendritic arbor, leading to subcellular specificity.

Secreted cues also direct the local clustering of presynaptic sites at specific subcellular locations in Caenorhabditis elegans neurons (Fig. 3B) (Colón-Ramos et al., 2007; Klassen and Shen, 2007; Poon et al., 2008). For example, the DA9 neuron in C. elegans forms en passant synapses with dorsal muscles and motor neurons along the anterior-posterior axis in the tail. Just posterior to where it forms these en passant synapses, the DA9 axon is devoid of presynaptic sites (Klassen and Shen, 2007). How are synapses confined to one specific region of the axon? Wnt/LIN-44 is secreted from hypodermal cells in the tip of the tail (Herman et al., 1995), and in mutants lacking $w n t / l i n-44$ or its receptor, fz/lin-17, DA9 synapses expanded into the asynaptic region. Both the number and intensity of synaptic puncta remained the same between wht/ lin-44 mutants and WT animals; the only observed change in $w n t / l i n-44$ mutants was a posterior shift in synapse position. Using a fluorescently tagged Fz/LIN-17, it was discovered that this receptor normally localizes exclusively to the asynaptic region of the DA9 axon; but in wnt/lin-44 mutants, Fz/LIN-17 was diffusely distributed along the DA9 axon. To test whether Wnt/LIN-44 is instructive for specifying the location of Fz/ LIN-17 clustering and thus DA9 synapses, wnt/lin-44 was ectopically expressed in a more anterior portion of the tail. This resulted in an anterior shift of both Fz/LIN-17 expression and DA9 synapses. These results suggest Wnt/LIN-44 promotes the clustering of Fz/LIN-17, and then Fz/LIN-17 locally inhibits presynapse clustering (Klassen and Shen, 2007). Therefore, the placement of presynaptic sites can be determined through secreted signals, and sculpted by inhibitory cues.

In other model systems, compartmentalized expression of CAMs combines with locally secreted cues to promote subcellular synapse specificity. For example, the Purkinje neurons of the cerebellum receive inputs from inhibitory basket cells at the axon initial segment (AIS) (Huang, 2006). The presynaptic basket cells express the NRP1 receptor, whereas the postsynaptic Purkinje cells express both the secreted signal SEMA3A and the CAM Neurofascin-186 (NF186). SEMA3A was found to be locally secreted from the Purkinje soma, transducing an attractive signal in the basket cell through the NRP1 receptor (Telley et al., 2016). Additionally, immunofluorescence showed that NF186 is present in a gradient on the Purkinje cell surface: highest at the AIS and lowest at the top of the soma (Ango et al., 2004). The trans-synaptic interaction between Purkinje NF186 and basket cell NRP1 ultimately results in synapse formation at the AIS (Telley et al., 2016). Thus, the targeting of the basket cell axon is initially refined by the locally secreted SEMA3A but is ultimately determined by trans-synaptic CAM interactions (Telley et al., 2016).

Recent RNA-seq approaches continue to expand our knowledge of molecular mechanisms that generate subcellular synaptic specificity. Favuzzi et al. (2019) asked whether distinct molecular programs could explain the observed subcellular targeting preferences among the interneurons that innervate cortical pyramidal neurons. At the time of synapse formation, they performed RNAseq on three populations of interneurons: $\mathrm{SST}^{+}$cells, $\mathrm{PV}^{+}$basket cells, and chandelier cells. These three cell types innervate the dendrites, soma, and AIS of pyramidal cells, respectively. Differentially expressed gene subsets were identified for each interneuron subtype. The most differentially enriched gene for each group was further characterized for its role in promoting subcellular synaptic specificity. Cbln4, a member of the C1q secreted protein family, was enriched in $\mathrm{SST}^{+}$cells; Lgi2, a secreted leucine-rich repeat protein, was enriched in $\mathrm{PV}^{+}$basket cells; and $\mathrm{Fg} 13$, an intracellular protein, was enriched in chandelier cells. Knockdown of each of these genes in their respective interneuron subtype resulted in a decrease in the number of synapses onto pyramidal cells. This result demonstrated that these genes are required for synapse formation, but do they instruct the ultimate subcellular location of synapses onto pyramidal cells? Indeed, overexpression of Cbln 4 in all three interneuron subtypes triggered ectopic synapse formation onto the dendritic domain alone (Favuzzi et al., 2019). This work raises many intriguing questions about how these identified molecules mediate subcellular synaptic specificity. Is there regional heterogeneity in the molecules used by interneurons across the brain to target specific subcellular regions of postsynaptic cells? How do CBLN4 and LGI2, which are both secreted proteins (Yuzaki, 2010; Kegel et al., 2013), signal back to the interneuron to indicate where to target? What molecules do they interact with on the pyramidal cell to mediate specificity?

\section{Neuronal activity establishes synaptic specificity}

Neuronal activity is an important mechanism by which circuitry is established, refined, and maintained. While some circuits can develop in the absence of activity (Di Cristo et al., 2004; Hiesinger et al., 2006; Klassen and Shen, 2007), spontaneous 
(McLaughlin et al., 2003; Antón-Bolaños et al., 2019; Wan et al., 2019; Akin and Zipursky, 2020) and sensory-evoked activity (Shatz and Stryker, 1978; LeVay et al., 1980) helps to organize circuits in other contexts, often within a critical period of development (LeVay et al., 1980; Jarecki and Keshishian, 1995; McLaughlin et al., 2003; Ackerman et al., 2020). Developmental neuronal activity is typically regarded as a process that refines the connectivity of established circuits. While this may be the case in some instances (Changeux and Danchin, 1976; Kapfer et al., 2002; McLaughlin et al., 2003; Valdes-Aleman et al., 2020), evidence has also emerged in recent years that neuronal activity induces patterns of gene expression that instruct the initial organization of circuit connectivity (Serizawa et al., 2006; Inoue et al., 2018; Nakashima et al., 2019).

The link between spontaneous activity and circuit establishment has been well studied in the mouse olfactory bulb, where primary olfactory sensory neurons (OSNs) expressing identical olfactory receptors converge onto the same glomeruli. The segregation of OSN axons into discrete glomeruli is an activity-dependent process (F. Wang et al., 1998; Yu et al., 2004), in which activity in OSNs triggers the expression of axon sorting molecules (Serizawa et al., 2006; Williams et al., 2010; Inoue et al., 2018). However, it was unclear until recently how activity could lead to the expression of different molecules in different sets of OSN axons. Nakashima et al. (2019) found that three subclasses of OSNs exhibited distinct patterns of spontaneous activity (i.e., tonic, short burst, and prolonged burst firing) during development. These activity patterns regulated expression levels of three different CAMs, which in turn promote glomerular organization (Fig. 3D). The authors distinguished between the Hebbian rule of "neurons that fire together, wire together," and their proposed model in which neurons that have similar spontaneous firing patterns wire together (Nakashima et al., 2019). As there are $>1000$ OSN subtypes in the mouse, it will be important to learn whether each subtype uses similar rules to establish proper glomerular targeting. In other words, are there $>1000$ distinct activity patterns that result in unique combinations of axon sorting molecule expression? Or does axon sorting arise from graded differences in spontaneous activity patterns, and thus expression levels of the identified CAMs?

\section{How are neural circuits maintained?}

The continuous function of the nervous system relies on the integrity of the circuits established during development. Indeed, the hallmark of many neurodegenerative diseases is a loss of synapses resulting in the destabilization of axons or dendrites (Terry et al., 1991; Scheff et al., 2006; Lin and Koleske, 2010; Hong et al., 2016; Mariano et al., 2018; Sauerbeck et al., 2020). Understanding how the architecture of the nervous system is maintained might therefore aid in the development of therapeutics that prevent or restore synapse loss in disease states. Efforts to characterize the molecular landscape of developing versus mature neurons demonstrate that the regulators of wiring that are present in development are largely downregulated in established circuits (H. Li et al., 2017; Favuzzi et al., 2019; J. Li et al., 2020). Therefore, a distinct set of molecular programs is likely required to maintain circuit architecture. Here, we summarize recent literature that examines how synaptic specificity, synapse location, and synapse stability are maintained.

\section{Maintenance of synaptic specificity during animal growth}

Advances in imaging technology and multidimensional image reconstruction have enabled rapid and repeated imaging across biological scales: from single synaptic proteins to whole-animal connectomes. From these advances, we see that the architecture of the nervous system is remarkably stable during postembryonic development. In Drosophila, the morphology and connectivity of neurons in a nociceptive circuit are consistent between first and third instar (Schneider-Mizell et al., 2016; Gerhard et al., 2017), during which the size of the neurons and number of synapses between synaptic partners are proportionally scaled to the animal's increased body size. The proportion of synaptic inputs from each presynaptic partner onto a given neuron is also consistent across development, suggesting that there are mechanisms to ensure reliable circuit output (Gerhard et al., 2017). A similar study was recently undertaken in C. elegans. The brains of 8 isogenic animals were imaged by serial-section electron microscopy at successive stages of development, and their connectomes were reconstructed. While considerable nonuniform changes in synapse addition took place during maturation, the shape and positioning of the majority of neurites established at birth remained consistent through adulthood. Roughly $\sim 70 \%$ of synapses in the adult brain were part of stable connections that maintained proportional strength from birth to adulthood (Witvliet et al., 2020). During such a dynamic process, how are specific connections between neurons maintained? It appears maintenance of synaptic specificity is enabled by both cell-autonomous and nonautonomous mechanisms.

The Drosophila larva is a tractable model for studying circuit maintenance during animal growth. From first to third instar, the body surface area increases 100-fold. During this time, neurons increase in size and synapse number while maintaining their overall topology (Parrish et al., 2009; Gerhard et al., 2017). Class IV da (C4da) sensory neurons synapse with A08n interneurons to mediate responses to noxious temperature and touch stimuli (Tracey et al., 2003; Hwang et al., 2007; Hu et al., 2017). Both light and electron microscopy studies of C4da-A08n connections show that the number of C4da synapses onto A08n linearly increases during larval growth; however, the proportion of C4da synapses targeting A08n is constant (Tenedini et al., 2019). Tao kinase was identified in a reverse genetic screen for molecular regulators that maintain cellular synaptic specificity. When knocked down in A08n using RNAi, A08n dendrites had more postsynaptic puncta and formed ectopic synapses with another class of sensory neuron, C3da. Conversely, overactivation of Tao resulted in a reduction in A08n dendritic volume and postsynapse number. Together, these results suggest that the maintenance of synaptic specificity during growth is partially accomplished through the restriction of dendrite overgrowth and synapse addition (Fig. 4A). Tao likely accomplishes this function through the negative regulation of dendritic cytoskeletal stability; loss of Tao expression was shown elsewhere to elevate the proportion of stable microtubules and levels of Factin in the dendrite ( $\mathrm{Hu}$ et al., 2020). Additionally, the human ortholog TaoK2 was able to substitute for Drosophila Tao function, suggesting that there is conservation between the fly and human Tao functional protein domains (Tenedini et al., 2019; Hu et al., 2020).

As discussed above, the subcellular placement of synapses is an important feature of circuit function and likewise must be maintained during animal growth. Maintenance of synaptic placement during growth has been termed "synaptic allometry." Synaptic allometry requires not only the maintenance of synapse positioning, but also the prevention of ectopic synapse accumulation (Fan et al., 2020). In C. elegans, coordinated signaling across multiple cell types underlies presynaptic allometry in a subset of neurons called AIY. The AIY neurons in the worm form synapses with different partners at stereotyped locations 
along their axons (Colón-Ramos et al., 2007). The locations of these synapses are established in the embryo and maintained in the adult (White et al., 1986; ColónRamos et al., 2007; Shao et al., 2013). CIMA-1, part of the SLC17 family of solute transporters, was identified in a forward genetic screen for regulators of AIY synaptic allometry. CIMA-1 was found to be expressed in epidermal cells of the adult. In cima-1 mutants, AIY presynapse position was normal in the newly hatched larva, but in adults, AIY presynapses were posteriorly displaced and ectopic presynapses formed in an area of the axon typically devoid of synapses (Shao et al., 2013). The ectopic synapses were not opposed to the main AIY postsynaptic partner neuron, RIA. Therefore, CIMA-1 is required for maintaining AIY presynapse subcellular position and potentially restricting inappropriate contacts from larval stages into the adult.

Interestngly, CIMA-1 exerts its effect on synapse maintenance by modifying the position of glial cells. A subset of glial cells (ventral cephalic sheath cells) occupies the space between the AIY synaptic zone and the CIMA-1-expressing epidermis (White et al., 1986). In cima-1 mutants, glial processes extend aberrantly and contact the AIY asynaptic zone. This aberrant glial positioning correlates with the establishment of ectopic AIY presynapses. To test whether glial cell contact is required for ectopic synapse accumulation in AIY, glial cells were genetically ablated in a cima-1 mutant background. As a result, AIY presynapses no longer extended into the AIY asynaptic zone. Through a secondary suppressor screen, the FGF receptor EGL-15 (5A) was found to be required in epidermal cells for distortion of glial morphology and thus ectopic synapse formation. Only the extracellular adhesive domain of EGL-15(5A) was required to suppress ectopic glial extension and ectopic synapse formation. In cima-1 mutants, EGL-15 (5A) levels were upregulated fivefold, indicating that CIMA-1 normally antagonizes EGL. These results suggest a model in which glia maintain the location of presynapses during growth (Fig. $4 B$ ), and this is enabled by reducing glia-epidermis adhesion. CIMA-1 reduces glia-epidermis adhesion, allowing glia location to be maintained, perhaps by preventing the retrograde extension of glial processes as animal length increases (Breau et al., 2017). As a result of maintaining glial position, the AIY synaptic pattern is retained (Shao et al., 2013). This study highlights how nonautonomous cues regulate synapse subcellular localization during the postembryonic phase of growth.

The mechanisms highlighted in this section restrain ectopic synapse addition. Dendritic expansion is negatively regulated to maintain cellular synaptic specificity, and non-neuronal cells help to affix the location of presynapses from embryonic stages to adulthood. In the following section, we examine how individual synapses are positively reinforced.

C loss.
Restrained growth

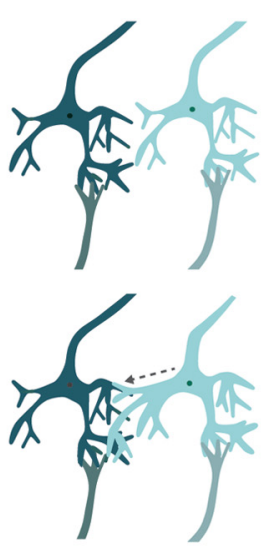

Structural reinforcement

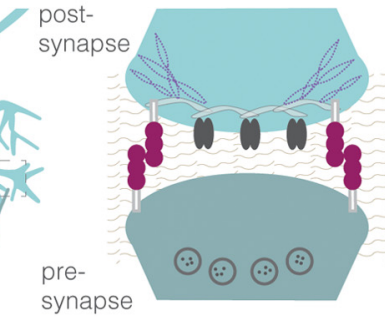

$\begin{array}{lll}\text { CAM } & \text { Scaffold } \\ \text { Synaptic } & & \\ \text { Vesicle } & \text { ECM } \\ \text { Actin } & \text { Receptor } \\ \text { Filament } & \text { n }\end{array}$

Figure 4. Mechanisms that promote neural circuit maintenance. $A$, Synaptic partnerships and circuit topology are retained through restricting dendritic overgrowth. $\boldsymbol{B}$, Synapse location is maintained through the positioning of glia-neuron CAM-intracellular scaffold-cytoskeletal interactions. $\boldsymbol{D}$, Silencing of neuronal activity can result in degeneration or neuron

\section{Maintenance of synaptic stability}

In mammals, dendritic spines are protrusions from the main dendritic shaft, and are the postsynaptic sites of excitatory synapses. Juvenile mice exhibit continual addition and retraction of individual dendritic spines and presynaptic terminals. As these animals enter adulthood, the rate of synapse turnover decreases (Gan et al., 2003; Zuo et al., 2005), with 70\% of cortical dendritic spines persisting at least 18 months (Zuo et al., 2005). In humans, the density of synapses is stable until advanced age (Huttenlocher, 1979). Thus, individual synapses may persist in the human brain for decades. Once a synapse is established, how does it persist?

The decrease in dendritic spine motility in adult animals coincides with the maturation of the extracellular matrix (ECM) (Frischknecht and Gundelfinger, 2012), a meshwork of glycoproteins and proteoglycans. Studies in the hippocampus and visual cortex have shown that ECM degradation in these areas causes increased spine addition and retraction, formation of filopodial protrusions, and dynamic changes in the size of the spine head (Oray et al., 2004; Orlando et al., 2012; de Vivo et al., 2013). Moreover, when ECM was degraded, Orlando et al. (2012) noted 
an increase in the clustering and activation of integrins, transmembrane proteins that have established roles in sensing changes to ECM (Park and Goda, 2016). When integrin activation was neutralized with an antagonistic antibody treatment, dendritic spine motility was blocked. Thus, in this system, ECM may inhibit integrin activation to stabilize dendritic spines (Orlando et al., 2012).

Synapse stability is also dependent on cell-cell adhesion to maintain the close apposition of presynaptic and postsynaptic compartments. Although many of the molecules that establish synaptic specificity are downregulated after circuit establishment (H. Li et al., 2017; Favuzzi et al., 2019; J. Li et al., 2020), subsets of CAMs are required to maintain synaptic stability (Robbins et al., 2010; Lin and Koleske, 2010; Soto et al., 2018). One example is L1CAM, part of the L1 family of IgSF cell surface molecules. L1CAM is required in the mouse cortex to establish and maintain synapses between presynaptic chandelier cells and postsynaptic pyramidal neurons. As stated earlier, chandelier cells form inhibitory synapses at the AIS of pyramidal neurons. In an RNAi screen for CAM regulators of synapse formation, Tai et al. (2019) found that knockdown of L1CAM in pyramidal neurons during the time of synapse formation greatly reduced the number of chandelier synapses onto pyramidal neurons. They next asked whether L1CAM is required to maintain synapses. Using a tamoxifen-inducible Cre system, they induced expression of L1CAM RNAi in adult mice (P28) and assayed for synapse loss $12 \mathrm{~d}$ later (P40). They found both the number of synapses and chandelier contacts onto pyramidal cell neurons were reduced (Tai et al., 2019). In Drosophila, the L1CAM homolog Neuroglian (Nrg) is also required to establish synaptic contact between neurons in the CNS, and to maintain synapse stability between motor neurons and muscles at the neuromuscular junction (Enneking et al., 2013).

Intracellularly, synapse stability requires the linkage between CAMs and the cytoskeleton. CAMs are linked to the cytoskeleton through a network of scaffolding proteins. For example, L1CAM and Nrg bind intracellularly to the Ankyrin scaffold protein. Ankyrin provides a link between CAMs and the submembranous cytoskeleton (Smith and Penzes, 2018). Accordingly, at the neuromuscular junction of Drosophila ank2 mutants, microtubule bundles within motor neurons are severely disorganized. CAMs are depleted and no longer stably associated with the synaptic membrane, leading to the retraction of synapses (Koch et al., 2008; Pielage et al., 2008; Enneking et al., 2013). Ankyrins also promote the clustering of CAMs and synaptic machinery at the AIS in vertebrate neurons (Smith and Penzes, 2018), and removal of either Ankyrin or $\beta$-spectrin results in a decrease in synaptic inputs onto the AIS (Ango et al., 2004; Tai et al., 2019).

ECM, cell-cell adhesion, intracellular scaffold proteins, and the cytoskeleton provide a rigid support network that allows the perdurance of individual synapses (Fig. 4C). While continuous brain function requires that circuit integrity be maintained, certain cognitive abilities, such as learning and memory, require that the brain retain the capacity to undergo structural circuit modifications. In the hippocampus, the region of the brain that processes new memories, synapses exhibit a relatively high degree of dynamicity compared with other brain regions (Pfeiffer et al., 2018). There is evidence from hippocampus and other brain regions to suggest that processes that directly oppose ECM and CAM stability allow flexible modification of synaptic structures (Oray et al., 2004; Frischknecht et al., 2009; Robbins et al., 2010; P.T. Nguyen et al., 2020). Future work will be necessary to understand the mechanisms underlying the regional heterogeneity of synapse stability, as well as how synapse destabilizing and stabilizing mechanisms are dynamically regulated during memory acquisition and retainment.

Neuronal activity is also important for maintaining synaptic connections (Fig. 4D). In studies where all neurons were chronically silenced during development, circuitry appeared to develop normally but ultimately resulted in axon degeneration (Verhage et al., 2000). Using a more refined approach, Yu et al. (2004) conditionally silenced a subpopulation of OSNs after olfactory glomeruli were established. In the following days, OSN axons migrated away from their initial glomerular target, and OSN cell numbers subsequently diminished (Yu et al., 2004). In $C$. elegans, axon branching defects have also been observed in sensory-deprived animals late in development (Peckol et al., 1999); thus, activity is possibly an evolutionarily conserved homeostatic mechanism for maintaining circuit organization. Further investigation is needed to determine what molecular programs are downstream of neuronal activity to reinforce existing connections.

\section{Conclusions and future areas of study}

Many neurons in the brain exhibit an exquisite precision in the formation of synaptic partnerships, as well as in the subcellular targeting of their synapses. The collective evidence from model systems fueled by improvements in methodologies suggests that cell surface molecules not only promote the matching of synaptic partners but also denote the subcellular placement of synapses. Secreted signaling molecules can refine the targeting of axons to specific subcellular domains of postsynaptic partners, as well as dictate the location of presynaptic sites. Both positive and negative cues sculpt the placement of synapses in certain subcellular compartments and exclude them in others. Finally, neuronal activity can play an instructive role in the establishment and maintenance of synaptic specificity.

There has also been excellent progress in understanding how neural circuit architecture is established and maintained. During the establishment phase, neurons are guided not just to regional domains by axon guidance cues, but also to specific subcellular locations of postsynaptic neurons. Once at their ultimate destination, many neurons are consistently able to synapse with a specific subset of neurons, despite the presence of many additional potential partners. Since Langley and Sperry first postulated the notion of chemoaffinity tags, studies have identified many cellsurface molecules that specify connectivity. Expanding on the chemoaffinity hypothesis, we have seen that secreted cues, interactions between neurons and glia, and neuronal activity are also critical for the precise organization of circuits. After circuit establishment has taken place, there are mechanisms that maintain individual synapses, synapse locations, and cellular synaptic specificity. New players, as well as some that are involved in synapse establishment, provide rigid support to presynaptic and postsynaptic structures.

While our understanding of how the architecture of the nervous system is established and maintained has certainly expanded, there are still a host of questions to be answered. In this review, we chose to focus on mechanisms underlying the wiring of highly deterministic circuits, but there are also examples of circuits with variable and stochastic wiring patterns (Chou et al., 2010; Caron et al., 2013; Linneweber et al., 2020; Witvliet et al., 2020). What are the rules used to wire up these circuits, and how are they different from more deterministic circuits? Importantly, how can we leverage principles of circuit establishment and 
maintenance to prevent or restore synapse loss in disease? The pathways described in this review could serve as entry points for the development of therapies for this purpose.

\section{References}

Ackerman SD, Perez-Catalan NA, Freeman MR, Doe CQ (2020) Astrocytes close a critical period of motor circuit plasticity. BioRxiv 098608. doi: 10.1101/2020.05.15.098608.

Akin O, Zipursky SL (2020) Activity regulates brain development in the fly. Curr Opin Genet Dev 65:8-13.

Allen NJ, Bennett ML, Foo LC, Wang GX, Chakraborty C, Smith SJ, Barres BA (2012) Astrocyte glypicans 4 and 6 promote formation of excitatory synapses via GluA1 AMPA receptors. Nature 486:410-414.

Ango F, di Cristo G, Higashiyama H, Bennett V, Wu P, Huang ZJ (2004) Ankyrin-based subcellular gradient of neurofascin, an immunoglobulin family protein, directs GABAergic innervation at Purkinje axon initial segment. Cell 119:257-272.

Ango F, Wu C, Van der Want JJ, Wu P, Schachner M, Huang ZJ (2008) Bergmann glia and the recognition molecule CHL1 organize GABAergic axons and direct innervation of Purkinje cell dendrites. PLoS Biol 6:e103.

Antinucci P, Nikolaou N, Meyer MP, Hindges R (2013) Teneurin-3 specifies morphological and functional connectivity of retinal ganglion cells in the vertebrate visual system. Cell Rep 5:582-592.

Antón-Bolaños N, Sempere-Ferràndez A, Guillamón-Vivancos T, Martini FJ, Pérez-Saiz L, Gezelius H, Filipchuk A, Valdeolmillos M, López-Bendito G (2019) Prenatal activity from thalamic neurons governs the emergence of functional cortical maps in mice. Science 364:987-990.

Ashley J, Sorrentino V, Lobb-Rabe M, Nagarkar-Jaiswal S, Tan L, Xu S, Xiao Q, Zinn K, Carrillo RA (2019) Transsynaptic interactions between IgSF proteins DIP- $\alpha$ and Dpr10 are required for motor neuron targeting specificity. Elife 8:e42690.

Ashrafi S, Betley JN, Comer JD, Brenner-Morton S, Bar V, Shimoda Y, Watanabe K, Peles E, Jessell TM, Kaltschmidt JA (2014) Neuronal Ig/ Caspr recognition promotes the formation of axoaxonic synapses in mouse spinal cord. Neuron 81:120-129.

Aurelio O, Hall DH, Hobert O (2002) Immunoglobulin-domain proteins required for maintenance of ventral nerve cord organization. Science 295:686-690.

Barish S, Nuss S, Strunilin I, Bao S, Mukherjee S, Jones CD, Volkan PC (2018) Combinations of DIPs and Dprs control organization of olfactory receptor neuron terminals in Drosophila. PLoS Genet 14:e1007560.

Bénard C, Tjoe N, Boulin T, Recio J, Hobert O (2009) The small, secreted immunoglobulin protein ZIG-3 maintains axon position in Caenorhabditis elegans. Genetics 183:917-927.

Berns DS, DeNardo LA, Pederick DT, Luo L (2018) Teneurin-3 controls topographic circuit assembly in the hippocampus. Nature 554:328-333.

Bloss EB, Cembrowski MS, Karsh B, Colonell J, Fetter RD, Spruston N (2016) Structured dendritic inhibition supports branch-selective integration in CA1 pyramidal cells. Neuron 89:1016-1030.

Breau MA, Bonnet I, Stoufflet J, Xie J, De Castro S, Schneider-Maunoury S (2017) Extrinsic mechanical forces mediate retrograde axon extension in a developing neuronal circuit. Nat Commun 8:282.

Caron SJ, Ruta V, Abbott LF, Axel R (2013) Random convergence of olfactory inputs in the Drosophila mushroom body. Nature 497:113-117.

Carrillo RA, Özkan E, Menon KP, Nagarkar-Jaiswal S, Lee PT, Jeon M, Birnbaum ME, Bellen HJ, Garcia KC, Zinn K (2015) Control of synaptic connectivity by a network of Drosophila IgSF cell surface proteins. Cell 163:1770-1782.

Changeux JP, Danchin A (1976) Selective stabilisation of developing synapses as a mechanism for the specification of neuronal networks. Nature 264:705-712.

Chédotal A (2019) Roles of axon guidance molecules in neuronal wiring in the developing spinal cord. Nat Rev Neurosci 20:380-396.

Chen PL, Clandinin TR (2008) The cadherin Flamingo mediates level-dependent interactions that guide photoreceptor target choice in Drosophila. Neuron 58:26-33.

Cheng S, Ashley J, Kurleto JD, Lobb-Rabe M, Park YJ, Carrillo RA, Özkan E (2019) Molecular basis of synaptic specificity by immunoglobulin superfamily receptors in Drosophila. Elife 8:e41028.
Chou YH, Spletter ML, Yaksi E, Leong JC, Wilson RI, Luo L (2010) Diversity and wiring variability of olfactory local interneurons in the Drosophila antennal lobe. Nat Neurosci 13:439-449.

Colón-Ramos DA, Margeta MA, Shen K (2007) Glia promote local synaptogenesis through UNC-6 (netrin) signaling in C. elegans. Science 318:103106.

Cosmanescu F, Katsamba PS, Sergeeva AP, Ahlsen G, Patel SD, Brewer JJ, Tan L, Xu S, Xiao Q, Nagarkar-Jaiswal S, Nern A, Bellen HJ, Zipursky SL, Honig B, Shapiro L (2018) Neuron-subtype-specific expression, interaction affinities, and specificity determinants of DIP/Dpr cell recognition proteins. Neuron 100:1385-1400.e6.

Courgeon M, Desplan C (2019) Coordination between stochastic and deterministic specification in the Drosophila visual system. Science 366: eaay6727.

de Vivo L, Landi S, Panniello M, Baroncelli L, Chierzi S, Mariotti L, Spolidoro M, Pizzorusso T, Maffei L, Ratto GM (2013) Extracellular matrix inhibits structural and functional plasticity of dendritic spines in the adult visual cortex. Nat Commun 4:1484.

de Wit J, Ghosh A (2016) Specification of synaptic connectivity by cell surface interactions. Nat Rev Neurosci 17:22-35.

Dean C, Dresbach T (2006) Neuroligins and neurexins: linking cell adhesion, synapse formation and cognitive function. Trends Neurosci 29:21-29.

DeNardo LA, de Wit J, Otto-Hitt S, Ghosh A (2012) NGL-2 regulates inputspecific synapse development in CA1 pyramidal neurons. Neuron $76: 762-775$

Dickson BJ (2002) Molecular mechanisms of axon guidance. Science 298:1959-1964.

Di Cristo G, Wu C, Chattopadhyaya B, Ango F, Knott G, Welker E, Svoboda K, Huang ZJ (2004) Subcellular domain-restricted GABAergic innervation in primary visual cortex in the absence of sensory and thalamic inputs. Nat Neurosci 7:1184-1186.

Duan X, Krishnaswamy A, De la Huerta I, Sanes JR (2014) Type II cadherins guide assembly of a direction-selective retinal circuit. Cell 158:793-807.

Dunah AW, Hueske E, Wyszynski M, Hoogenraad CC, Jaworski J, Pak DT, Simonetta A, Liu G, Sheng M (2005) LAR receptor protein tyrosine phosphatases in the development and maintenance of excitatory synapses. Nat Neurosci 8:458-467.

Enneking EM, Kudumala SR, Moreno E, Stephan R, Boerner J, Godenschwege TA, Pielage J (2013) Transsynaptic coordination of synaptic growth, function, and stability by the L1-type CAM neuroglian. PLoS Biol 11:e1001537.

Fan J, Ji T, Wang K, Huang J, Wang M, Manning L, Dong X, Shi Y, Zhang X, Shao Z, Colón-Ramos DA (2020) A muscle-epidermis-glia signaling axis sustains synaptic specificity during allometric growth in Caenorhabditis elegans. Elife 9:e55890.

Favuzzi E, Deogracias R, Marques-Smith A, Maeso P, Jezequel J, ExpositoAlonso D, Balia M, Kroon T, Hinojosa AJ, Maraver E, Rico B (2019) Distinct molecular programs regulate synapse specificity in cortical inhibitory circuits. Science 363:413-417.

Frischknecht R, Gundelfinger ED (2012) The brain's extracellular matrix and its role in synaptic plasticity. Adv Exp Med Biol 970:153-171.

Frischknecht R, Heine M, Perrais D, Seidenbecher CI, Choquet D, Gundelfinger ED (2009) Brain extracellular matrix affects AMPA receptor lateral mobility and short-term synaptic plasticity. Nat Neurosci 12:897-904

Früh S, Romanos J, Panzanelli P, Bürgisser D, Tyagarajan SK, Campbell KP, Santello M, Fritschy JM (2016) Neuronal dystroglycan is necessary for formation and maintenance of functional CCK-positive basket cell terminals on pyramidal cells. J Neurosci 36:10296-10313.

Gan WB, Kwon E, Feng G, Sanes JR, Lichtman JW (2003) Synaptic dynamism measured over minutes to months: age-dependent decline in an autonomic ganglion. Nat Neurosci 6:956-960.

Gerhard S, Andrade I, Fetter RD, Cardona A, Schneider-Mizell CM (2017) Conserved neural circuit structure across Drosophila larval development revealed by comparative connectomics. Elife 6:e29089.

Hao J, Wang X, Dan Y, Poo M, Zhang X (2009) An arithmetic rule for spatial summation of excitatory and inhibitory inputs in pyramidal neurons. Proc Natl Acad Sci USA 106:21906-21911.

Herman MA, Vassilieva LL, Horvitz HR, Herman RK (1995) The C. elegans gene lin-44, which controls the polarity of certain asymmetric cell divisions, encodes a Wnt protein and acts cell nonautonomously. Cell 83:101-110. 
Hiesinger PR, Zhai RG, Zhou Y, Koh TW, Mehta SQ, Schulze KL, Cao Y, Verstreken P, Clandinin TR, Fischbach KF, Meinertzhagen IA, Bellen HJ (2006) Activity-independent prespecification of synaptic partners in the visual map of Drosophila. Curr Biol 16:1835-1843.

Hildebrand DG, Cicconet M, Torres RM, Choi W, Quan TM, Moon J, Wetzel AW, Champion AS, Graham BJ, Randlett O, Plummer GS, Portugues R, Bianco IH, Saalfeld S, Baden AD, Lillaney K, Burns R, Vogelstein JT, Schier AF, Lee WC, et al. (2017) Whole-brain serial-section electron microscopy in larval zebrafish. Nature 545:345-349.

Hong S, Beja-Glasser VF, Nfonoyim BM, Frouin A, Li S, Ramakrishnan S, Merry KM, Shi Q, Rosenthal A, Barres BA, Lemere CA, Selkoe DJ, Stevens B (2016) Complement and microglia mediate early synapse loss in Alzheimer mouse models. Science 352:712-716.

Hong W, Mosca TJ, Luo L (2012) Teneurins instruct synaptic partner matching in an olfactory map. Nature 484:201-207.

Hu C, Petersen M, Hoyer N, Spitzweck B, Tenedini F, Wang D, Gruschka A, Burchardt LS, Szpotowicz E, Schweizer M, Guntur AR, Yang CH, Soba P (2017) Sensory integration and neuromodulatory feedback facilitate Drosophila mechanonociceptive behavior. Nat Neurosci 20:1085-1095.

Hu C, Kanellopoulos AK, Richter M, Petersen M, Konietzny A, Tenedini FM, Hoyer N, Cheng L, Poon CL, Harvey KF, Windhorst S, Parrish JZ, Mikhaylova M, Bagni C, Anda FC, de Soba P (2020) Conserved Tao kinase activity regulates dendritic arborization, cytoskeletal dynamics, and sensory function in Drosophila. J Neurosci 40:1819-1833.

Huang ZJ (2006) Subcellular organization of GABAergic synapses: role of ankyrins and L1 cell adhesion molecules. Nat Neurosci 9:163-166.

Huttenlocher PR (1979) Synaptic density in human frontal cortex: developmental changes and effects of aging. Brain Res 163:195-205.

Hwang RY, Zhong L, Xu Y, Johnson T, Zhang F, Deisseroth K, Tracey WD (2007) Nociceptive neurons protect Drosophila larvae from parasitoid wasps. Curr Biol 17:2105-2116.

Inoue N, Nishizumi H, Naritsuka H, Kiyonari H, Sakano H (2018) Sema7A/ $\mathrm{PlxnCl}$ signaling triggers activity-dependent olfactory synapse formation. Nat Commun 9:1842.

Jarecki J, Keshishian H (1995) Role of neural activity during synaptogenesis in Drosophila. J Neurosci 15:8177-8190.

Kapfer C, Seidl AH, Schweizer H, Grothe B (2002) Experience-dependent refinement of inhibitory inputs to auditory coincidence-detector neurons. Nat Neurosci 5:247-253.

Kasthuri N, Hayworth KJ, Berger DR, Schalek RL, Conchello JA, KnowlesBarley S, Lee D, Vázquez-Reina A, Kaynig V, Jones TR, Roberts M, Morgan JL, Tapia JC, Seung HS, Roncal WG, Vogelstein JT, Burns R, Sussman DL, Priebe CE, Pfister H, et al. (2015) Saturated reconstruction of a volume of neocortex. Cell 162:648-661.

Kegel L, Aunin E, Meijer D, Bermingham JR (2013) LGI proteins in the nervous system. ASN Neuro 5:AN20120095.

Keleman K, Dickson BJ (2001) Short- and long-range repulsion by the Drosophila Unc5 netrin receptor. Neuron 32:605-617.

Kerschensteiner D, Morgan JL, Parker ED, Lewis RM, Wong RO (2009) Neurotransmission selectively regulates synapse formation in parallel circuits in vivo. Nature 460:1016-1020.

Klassen MP, Shen K (2007) Wnt signaling positions neuromuscular connectivity by inhibiting synapse formation in C. elegans. Cell 130:704-716.

Koch I, Schwarz H, Beuchle D, Goellner B, Langegger M, Aberle H (2008) Drosophila ankyrin 2 is required for synaptic stability. Neuron 58:210222.

Kolodkin AL, Tessier-Lavigne M (2011) Mechanisms and molecules of neuronal wiring: a primer. Cold Spring Harb Perspect Biol 3:a001727.

Krishnaswamy A, Yamagata M, Duan X, Hong YK, Sanes JR (2015) Sidekick 2 directs formation of a retinal circuit that detects differential motion. Nature 524:466-470.

Kurusu M, Cording A, Taniguchi M, Menon K, Suzuki E, Zinn K (2008) A screen of cell-surface molecules identifies leucine-rich repeat proteins as key mediators of synaptic target selection. Neuron 59:972-985.

Kuwako KI, Nishimoto Y, Kawase S, Okano HJ, Okano H (2014) Cadherin-7 regulates mossy fiber connectivity in the cerebellum. Cell Rep 9:311-323.

Langley JN (1895) Note on regeneration of Prae-ganglionic fibres of the sympathetic. J Physiol 18:280-284.

Lee CH, Herman T, Clandinin TR, Lee R, Zipursky SL (2001) N-Cadherin regulates target specificity in the Drosophila visual system. Neuron 30:437-450.
LeVay S, Wiesel TN, Hubel DH (1980) The development of ocular dominance columns in normal and visually deprived monkeys. J Comp Neurol 191:1-51.

Li H, Horns F, Wu B, Xie Q, Li J, Li T, Luginbuhl DJ, Quake SR, Luo L (2017) Classifying Drosophila olfactory projection neuron subtypes by single-cell RNA sequencing. Cell 171:1206-1220.e22.

Li J, Han S, Li H, Udeshi ND, Svinkina T, Mani DR, Xu C, Guajardo R, Xie Q, Li T, Luginbuhl DJ, Wu B, McLaughlin CN, Xie A, Kaewsapsak P, Quake SR, Carr SA, Ting AY, Luo L (2020) Cell-surface proteomic profiling in the fly brain uncovers wiring regulators. Cell 180:373-386.e15.

Lin YC, Koleske AJ (2010) Mechanisms of synapse and dendrite maintenance and their disruption in psychiatric and neurodegenerative disorders. Annu Rev Neurosci 33:349-378.

Linneweber GA, Andriatsilavo M, Dutta SB, Bengochea M, Hellbruegge L, Liu G, Ejsmont RK, Straw AD, Wernet M, Hiesinger PR, Hassan BA (2020) A neurodevelopmental origin of behavioral individuality in the Drosophila visual system. Science 367:1112-1119.

Lüthy K, Ahrens B, Rawal S, Lu Z, Tarnogorska D, Meinertzhagen IA, Fischbach KF (2014) The irre cell recognition module (IRM) protein Kirre is required to form the reciprocal synaptic network of L4 neurons in the Drosophila lamina. J Neurogenet 28:291-301.

Mariano V, Domínguez-Iturza N, Neukomm LJ, Bagni C (2018) Maintenance mechanisms of circuit-integrated axons. Curr Opin Neurobiol 53:162-173.

Mark B, Lai SL, Zarin AA, Manning L, Cardona A, Truman JW, Doe CQ (2019) The role of lineage, hemilineage and temporal identity in establishing neuronal connectivity in the Drosophila larval CNS. BiorXiv 617936. doi: 10.1101/617936.

Martin EA, Muralidhar S, Wang Z, Cervantes DC, Basu R, Taylor MR, Hunter J, Cutforth T, Wilke SA, Ghosh A, Williams ME (2015) The intellectual disability gene Kirrel3 regulates target-specific mossy fiber synapse development in the hippocampus. Elife 4:e09395.

McLaughlin T, Torborg CL, Feller MB, O’Leary DD (2003) Retinotopic map refinement requires spontaneous retinal waves during a brief critical period of development. Neuron 40:1147-1160.

Menon KP, Kulkarni V, Takemura S, Anaya M, Zinn K (2019) Interactions between Dpr11 and DIP- $\gamma$ control selection of amacrine neurons in Drosophila color vision circuits. Elife 8:e48935.

Miles R, Tóth K, Gulyás AI, Hájos N, Freund TF (1996) Differences between somatic and dendritic inhibition in the hippocampus. Neuron 16:815823.

Mizumoto K, Shen K (2013) Interaxonal interaction defines tiled presynaptic innervation in C. elegans. Neuron 77:655-666.

Mosca TJ, Hong W, Dani VS, Favaloro V, Luo L (2012) Trans-synaptic Teneurin signalling in neuromuscular synapse organization and target choice. Nature 484:237-241.

Mountoufaris G, Chen WV, Hirabayashi Y, O'Keeffe S, Chevee M, Nwakeze CL, Polleux F, Maniatis T (2017) Multicluster Pcdh diversity is required for mouse olfactory neural circuit assembly. Science 356:411-414.

Nakamura M, Baldwin D, Hannaford S, Palka J, Montell C (2002) Defective proboscis extension response (DPR), a member of the Ig superfamily required for the gustatory response to salt. J Neurosci 22:3463-3472.

Nakashima A, Ihara N, Shigeta M, Kiyonari H, Ikegaya Y, Takeuchi H (2019) Structured spike series specify gene expression patterns for olfactory circuit formation. Science 365:eaaw5030.

Nguyen AQ, Sutley S, Koeppen J, Mina K, Woodruff S, Hanna S, Vengala A, Hickmott PW, Obenaus A, Ethell IM (2020) Astrocytic ephrin-B1 controls excitatory-inhibitory balance in developing hippocampus. J Neurosci 40:6854-6871

Nguyen PT, Dorman LC, Pan S, Vainchtein ID, Han RT, Nakao-Inoue H, Taloma SE, Barron JJ, Molofsky AB, Kheirbek MA, Molofsky AV (2020) Microglial remodeling of the extracellular matrix promotes synapse plasticity. Cell. Cell 182:388-403.e15.

Nose A, Umeda T, Takeichi M (1997) Neuromuscular target recognition by a homophilic interaction of connectin cell adhesion molecules in Drosophila. Development 124:1433-1441

Oray S, Majewska A, Sur M (2004) Dendritic spine dynamics are regulated by monocular deprivation and extracellular matrix degradation. Neuron 44:1021-1030

Orlando C, Ster J, Gerber U, Fawcett JW, Raineteau O (2012) Perisynaptic chondroitin sulfate proteoglycans restrict structural plasticity in an integrin-dependent manner. J Neurosci 32:18009-18017. 
Özkan E, Carrillo RA, Eastman CL, Weiszmann R, Waghray D, Johnson KG, Zinn K, Celniker SE, Garcia KC (2013) An extracellular interactome of immunoglobulin and LRR proteins reveals receptor-ligand networks. Cell 154:228-239.

Park YK, Goda Y (2016) Integrins in synapse regulation. Nat Rev Neurosci 17:745-756.

Parrish JZ, Xu P, Kim CC, Jan LY, Jan YN (2009) The microRNA bantam functions in epithelial cells to regulate scaling growth of dendrite arbors in Drosophila sensory neurons. Neuron 63:788-802.

Peckol EL, Zallen JA, Yarrow JC, Bargmann CI (1999) Sensory activity affects sensory axon development in C. elegans. Development 126:1891-1902.

Pfeiffer T, Poll S, Bancelin S, Angibaud J, Inavalli VK, Keppler K, Mittag M, Fuhrmann M, Nägerl UV (2018) Chronic 2P-STED imaging reveals high turnover of dendritic spines in the hippocampus in vivo. Elife 7:e34700.

Pielage J, Cheng L, Fetter RD, Carlton PM, Sedat JW, Davis GW (2008) A presynaptic giant ankyrin stabilizes the NMJ through regulation of presynaptic microtubules and transsynaptic cell adhesion. Neuron 58:195209.

Poon VY, Klassen MP, Shen K (2008) UNC-6/netrin and its receptor UNC-5 locally exclude presynaptic components from dendrites. Nature 455:669673.

Pouille F, Watkinson O, Scanziani M, Trevelyan AJ (2013) The contribution of synaptic location to inhibitory gain control in pyramidal cells. Physiol Rep 1:e00067.

Prakash S, Caldwell JC, Eberl DF, Clandinin TR (2005) Drosophila N-cadherin mediates an attractive interaction between photoreceptor axons and their targets. Nat Neurosci 8:443-450.

Prieto-Godino LL, Diegelmann S, Bate M (2012) Embryonic origin of olfactory circuitry in Drosophila: contact and activity-mediated interactions pattern connectivity in the antennal lobe. PLoS Biol 10:e1001400.

Robbins EM, Krupp AJ, Perez de Arce K, Ghosh AK, Fogel AI, Boucard A, Südhof TC, Stein V, Biederer T (2010) SynCAM 1 adhesion dynamically regulates synapse number and impacts plasticity and learning. Neuron 68:894-906.

Sales EC, Heckman EL, Warren TL, Doe CQ (2019) Regulation of subcellular dendritic synapse specificity by axon guidance cues. Elife 8:e43478.

Sanes JR, Yamagata M (2009) Many paths to synaptic specificity. Annu Rev Cell Dev Biol 25:161-195.

Sanes JR, Zipursky SL (2020) Synaptic specificity, recognition molecules, and assembly of neural circuits. Cell 181:536-556.

Sauerbeck AD, Gangolli M, Reitz SJ, Salyards MH, Kim SH, Hemingway C, Gratuze M, Makkapati T, Kerschensteiner M, Holtzman DM, Brody DL, Kummer TT (2020) SEQUIN multiscale imaging of mammalian central synapses reveals loss of synaptic connectivity resulting from diffuse traumatic brain injury. Neuron 107:257-273.e5.

Scheff SW, Price DA, Schmitt FA, Mufson EJ (2006) Hippocampal synaptic loss in early Alzheimer's disease and mild cognitive impairment. Neurobiol Aging 27:1372-1384.

Scheffer LK (2020) A connectome and analysis of the adult Drosophila central brain. Elife 9:e57443.

Schneider-Mizell CM, Gerhard S, Longair M, Kazimiers T, Li F, Zwart MF, Champion A, Midgley FM, Fetter RD, Saalfeld S, Cardona A (2016) Quantitative neuroanatomy for connectomics in Drosophila. Elife 5: e12059.

Schubert T, Hoon M, Euler T, Lukasiewicz PD, Wong RO (2013) Developmental regulation and activity-dependent maintenance of GABAergic presynaptic inhibition onto rod bipolar cell axonal terminals. Neuron 78:124-137.

Schuster CM, Davis GW, Fetter RD, Goodman CS (1996) Genetic dissection of structural and functional components of synaptic plasticity: I. Fasciclin II controls synaptic stabilization and growth. Neuron 17:641-654.

Schwabe T, Neuert H, Clandinin TR (2013) A network of cadherin-mediated interactions polarizes growth cones to determine targeting specificity. Cell 154:351-364.

Sergeeva AP, Katsamba PS, Cosmanescu F, Brewer JJ, Ahlsen G, Mannepalli S, Shapiro L, Honig B (2020) DIP/Dpr interactions and the evolutionary design of specificity in protein families. Nat Commun 11:2125.

Serizawa S, Miyamichi K, Takeuchi H, Yamagishi Y, Suzuki M, Sakano H (2006) A neuronal identity code for the odorant receptor-specific and activity-dependent axon sorting. Cell 127:1057-1069.
Shao Z, Watanabe S, Christensen R, Jorgensen EM, Colón-Ramos DA (2013) Synapse location during growth depends on glia location. Cell 154:337350.

Shatz CJ, Stryker MP (1978) Ocular dominance in layer IV of the cat's visual cortex and the effects of monocular deprivation. J Physiol 281:267-283.

Shen K, Bargmann CI (2003) The immunoglobulin superfamily protein SYG-1 determines the location of specific synapses in C. elegans. Cell 112:619-630.

Shen K, Fetter RD, Bargmann CI (2004) Synaptic specificity is generated by the synaptic guidepost protein SYG-2 and its receptor, SYG-1. Cell 116:869-881.

Smith KR, Penzes P (2018) Ankyrins: roles in synaptic biology and pathology. Mol Cell Neurosci 91:131-139.

Soto F, Watkins KL, Johnson RE, Schottler F, Kerschensteiner D (2013) NGL-2 regulates pathway-specific neurite growth and lamination, synapse formation, and signal transmission in the retina. J Neurosci 33:11949-11959.

Soto F, Zhao L, Kerschensteiner D (2018) Synapse maintenance and restoration in the retina by NGL2. Elife 7:e30388.

Sperry RW (1943) Visuomotor coordination in the newt (Triturus viridescens) after regeneration of the optic nerve. J Comp Neurol 79:33-55.

Sperry RW (1944) Optic nerve regeneration with return of vision in anurans. J Neurophysiol 7:57-69.

Sperry RW (1963) Chemoaffinity in the orderly growth of nerve fiber patterns and connections. Proc Natl Acad Sci USA 50:703-710.

Tai Y, Gallo NB, Wang M, Yu JR, Van Aelst L (2019) Axo-axonic innervation of neocortical pyramidal neurons by GABAergic chandelier cells requires ankyrinG-associated L1CAM. Neuron 102:358-372.e9.

Tan L, Zhang KX, Pecot MY, Nagarkar-Jaiswal S, Lee PT, Takemura SY, McEwen JM, Nern A, Xu S, Tadros W, Chen Z, Zinn K, Bellen HJ, Morey M, Zipursky SL (2015) Ig superfamily ligand and receptor pairs expressed in synaptic partners in Drosophila. Cell 163:1756-1769.

Telley L, Cadilhac C, Cioni JM, Saywell V, Jahannault-Talignani C, Huettl RE, Sarrailh-Faivre C, Dayer A, Huber AB, Ango F (2016) Dual function of NRP1 in axon guidance and subcellular target recognition in cerebellum. Neuron 91:1276-1291.

Tenedini FM, Sáez González M, Hu C, Pedersen LH, Petruzzi MM, Spitzweck B, Wang D, Richter M, Petersen M, Szpotowicz E, Schweizer M, Sigrist SJ, Calderon de Anda F, Soba P (2019) Maintenance of cell type-specific connectivity and circuit function requires Tao kinase. Nat Commun 10:3506.

Terry RD, Masliah E, Salmon DP, Butters N, DeTeresa R, Hill R, Hansen LA, Katzman R (1991) Physical basis of cognitive alterations in Alzheimer's disease: synapse loss is the major correlate of cognitive impairment. Ann Neurol 30:572-580.

Tobin WF, Wilson RI, Lee WC (2017) Wiring variations that enable and constrain neural computation in a sensory microcircuit. Elife 6:e00067.

Tracey WD, Wilson RI, Laurent G, Benzer S (2003) Painless, a Drosophila gene essential for nociception. Cell 113:261-273.

Vaddadi N, Iversen K, Raja R, Phen A, Brignall A, Dumontier E, Cloutier JF (2019) Kirrel2 is differentially required in populations of olfactory sensory neurons for the targeting of axons in the olfactory bulb. Development 146:dev173310.

Valdes-Aleman J, Fetter RD, Sales EC, Heckman EL, Venkatasubraamanian L, Doe CQ, Landgraf M, Cardona A, Zlatic M (2020) Comparative connectomics reveals how partner identity, location, and activity specify synaptic connectivity in Drosophila. Neuron 109:1-18.

Verhage M, Maia AS, Plomp JJ, Brussaard AB, Heeroma JH, Vermeer H, Toonen RF, Hammer RE, van den Berg TK, Missler M, Geuze HJ, Südhof TC (2000) Synaptic assembly of the brain in the absence of neurotransmitter secretion. Science 287:864-869.

Wan Y, Wei Z, Looger LL, Koyama M, Druckmann S, Keller PJ (2019) Single-cell reconstruction of emerging population activity in an entire developing circuit. Cell 179:355-372.e23.

Wang F, Nemes A, Mendelsohn M, Axel R (1998) Odorant receptors govern the formation of a precise topographic map. Cell 93:47-60.

Wang L, Guo W, Shen X, Yeo S, Long H, Wang Z, Lyu Q, Herbison AE, Kuang Y (2020) Different dendritic domains of the GnRH neuron underlie the pulse and surge modes of GnRH secretion in female mice. Elife 9: e53945. 
White JG, Southgate E, Thomson JN, Brenner S (1986) The structure of the nervous system of the nematode Caenorhabditis elegans. Philos Trans R Soc Lond B Biol Sci 314:1-340.

Williams ME, de Wit J, Ghosh A (2010) Molecular mechanisms of synaptic specificity in developing neural circuits. Neuron 68:9-18.

Witvliet D, Mulcahy B, Mitchell JK, Meirovitch Y, Berger DR, Wu Y, Liu Y, Koh WX, Parvathala R, Holmyard D, Schalek RL, Shavit N, Chisholm AD, Lichtman JW, Samuel AD, Zhen M (2020) Connectomes across development reveal principles of brain maturation in C. elegans. BioRxiv 066209. doi: 10.1101/2020.04.30.066209.

Woo J, Kwon SK, Choi S, Kim S, Lee JR, Dunah AW, Sheng M, Kim E (2009) Trans-synaptic adhesion between NGL-3 and LAR regulates the formation of excitatory synapses. Nat Neurosci 12:428-437.

Xie Q, Wu B, Li J, Xu C, Li H, Luginbuhl DJ, Wang X, Ward A, Luo L (2019) Transsynaptic Fish-lips signaling prevents misconnections between nonsynaptic partner olfactory neurons. Proc Natl Acad Sci USA 116:1606816073.

Xie X, Tabuchi M, Brown MP, Mitchell SP, Wu MN, Kolodkin AL (2017) The laminar organization of the Drosophila ellipsoid body is semaphorin-dependent and prevents the formation of ectopic synaptic connections. Elife 6:e25328.

Xu C, Theisen E, Maloney R, Peng J, Santiago I, Yapp C, Werkhoven Z, Rumbaut E, Shum B, Tarnogorska D, Borycz J, Tan L, Courgeon M, Griffin T, Levin R, Meinertzhagen IA, de Bivort B, Drugowitsch J, Pecot
MY (2019) Control of synaptic specificity by establishing a relative preference for synaptic partners. Neuron 103:865-877.e7.

Xu S, Xiao Q, Cosmanescu F, Sergeeva AP, Yoo J, Lin Y, Katsamba PS, Ahlsen G, Kaufman J, Linaval NT, Lee PT, Bellen HJ, Shapiro L, Honig B, Tan L, Zipursky SL (2018) Interactions between the Ig-superfamily proteins DIP- $\alpha$ and Dpr6/10 regulate assembly of neural circuits. Neuron. Neuron 100:1369-1384.e6.

Yamagata M, Sanes JR (2008) Dscam and Sidekick proteins direct laminaspecific synaptic connections in vertebrate retina. Nature 451:465-469.

Yamagata M, Weiner JA, Sanes JR (2002) Sidekicks: synaptic adhesion molecules that promote lamina-specific connectivity in the retina. Cell 110:649-660.

Yu CR, Power J, Barnea G, O’Donnell S, Brown HE, Osborne J, Axel R, Gogos JA (2004) Spontaneous neural activity is required for the establishment and maintenance of the olfactory sensory map. Neuron 42:553566.

Yuzaki M (2010) Synapse formation and maintenance by C1q family proteins: a new class of secreted synapse organizers. Eur J Neurosci 32:191197.

Zonta B, Desmazieres A, Rinaldi A, Tait S, Sherman DL, Nolan MF, Brophy PJ (2011) A critical role for Neurofascin in regulating action potential initiation through maintenance of the axon initial segment. Neuron 69:945956.

Zuo Y, Lin A, Chang P, Gan WB (2005) Development of long-term dendritic spine stability in diverse regions of cerebral cortex. Neuron 46:181-189. 